\title{
Evaluation of in vitro Protein Digestibility of Different Feed Ingredients for Walking Catfish (Clarias batrachus Linnaeus, 1758)
}

\author{
Sudip Debnath ${ }^{1 *}$, Md. Shahin Parvez ${ }^{2}$, Sheikh Tareq Arafat ${ }^{1}$, Md. Mehedi Hasan ${ }^{2}$, \\ Md. Ayaz Hasan Chisty ${ }^{3}$ \\ ${ }^{1}$ Assistant Professor, Fisheries and Marine Resource Technology Discipline, Khulna University, Khulna-9208, \\ Bangladesh \\ ${ }^{2}$ Lecturer, Fisheries and Marine Resource Technology Discipline, Khulna University, Khulna-9208, Bangladesh \\ ${ }^{3}$ Professor, Fisheries and Marine Resource Technology Discipline, Khulna University, Khulna-9208, \\ Bangladesh
}

*Corresponding Author: Sudip Debnath, Assistant Professor, Fisheries and Marine Resource Technology Discipline, Khulna University, Khulna-9208, Bangladesh

\begin{abstract}
To determine relative protein digestibility (RPD) of different feed ingredients for walking catfish (Clarias batrachus) locally known as Magur, in vitro technique was conducted. Gut enzyme extracted from the experimental species was used to assay RPD through $\mathrm{pH}$ drop method. Higher relative protein digestibility was obtained from Meat \& Bone meal (94.92 $\pm 0.00 \%)$, followed by Fish meal (86.44 $\pm 1.69 \%)$, Soybean meal $(74.01 \pm 2.59 \%)$ and Mustard oil cake $(69.49 \pm 0.00 \%)$ and the lowest was observed from Rice polishing (33.90 $\pm 0.00 \%)$.From the result it is assumed that Meat \& Bone meal, Fish meal and Soybean meal would be the alternative protein sources of Fish meal for cost effective diet preparation of C. batrachus.
\end{abstract}

Keywords: Relative protein digestibility, in vitro technique, feed ingredients, Clarias batrachus

\section{INTRODUCTION}

With increasing global production, aquaculture is now one of the most rapidly developing sectors in Bangladesh. In any successful aquaculture business, the biggest cost of growing a fish is the feed, representing up to $60 \%$ of the total variable cost that must be nutritionally adequate and commercial for the sound operation of a fish farm [1].

Fish require some major nutrients such as protein, fat, carbohydrate, vitamins and minerals, but these requirements vary by species. Fish use proteins as their energy source and proteins must be used only for growth in fish [2].Increase in dietary protein has often been associated with higher growth rate in many species. However, there is a certain level beyond which further growth is not supported, and may even decrease [3].Furthermore, dietary protein content represents a major cost in preparation of fish diets. Therefore, it is essential to determine the optimum dietary protein level for the healthy growth of fish. So knowledge of digestibility of the various dietary ingredients is a basic requirement for formulating a diet [4]. Determining the digestibility of nutrients in feedstuffs is important not only to enable formulation of diets that maximize the growth of cultured fish by providing appropriate amounts of available nutrients, but also to limit the wastes produced by the fish [5].

The direct way to assess digestibility is to feed the animals with the ingredient or feed, and then collect the feces and perform the analyses necessary to estimate digestibility. However, this in vivo approach is laborious, time consuming and subject to a number of methodological limitations. In vitro methods to assess digestibility are relatively more convenient, widely adaptable, and easier to replicate [6].In vitro methods allow close observations of the dynamics of the breakdown of protein by using only small amount of raw materials [7]. This method may not replace the apparent digestibility trials but it can be used to assess the potential digestibility of a particular feedstuff [8] and it has been adapted to predict the protein digestibility of fish feed [9].

Air breathing walking catfish (Clarias batrachus, Family Clariidae), locally known as Magur, is a fish of great demand and attracts the attention of farmers for its high market value and growth rate, disease 
resistance and amenability to high-density culture, related to their air-breathing habits [10]. This species is very much popular in Bangladesh for several reasons. Firstly, they are important part of the diet for children and lactating mothers and also prescribed as diet for the convalescent of the patients. Furthermore the species can be kept alive for long time by storing in a water container without giving any food as the species bear special accessory respiratory organ. This fish is highly regarded for food due to its high protein (15.0\%), low fat (1.0\%) and high iron content $(710 \mathrm{mg} / 100 \mathrm{~g}$ tissue) [11].

Nutritionally well-balanced feeds are needed for intensive $C$. batrachus culture. Thus, knowledge on the specific requirements of $C$. batrachus is essential for the formulation of a well-balanced supplemental feed for successful intensive culture. Therefore, the aim of this study was to compare the relative protein digestibility coefficients of animal and plant protein feedstuffs and compound diets determined by an in vitro method.

\section{MATERIALS AND MeTHODS}

\subsection{Profile of the Study Area}

The Experiment was conducted at the Fish Nutrition Lab. and Wet Lab of Fisheries and Marine Resource Technology (FMRT) Discipline of Khulna University.

\subsection{Proximate Analysis of Different Feed Ingredients}

Five different types of feed ingredients viz. meat and bone meal, soybean meal, fish meal, mustard oilcake and rice polishing were collected from the local market and subjected for protein analysis and moisture determination (Table 1). All the ingredients were homogenized separately by grinding. The protein level of each ingredient was determined according to the AOAC methods [12].

Table1. Proximate composition of different feed ingredients

\begin{tabular}{|l|lc|}
\hline Feed ingredients & \multicolumn{2}{|c|}{ Proximate composition (\% in DMB) } \\
\hline \multirow{3}{*}{ Fish meal (FM) } & Protein\% & Moisture\% \\
\cline { 2 - 3 } Soybean meal (SM) & $53.35 \pm 0.29$ & 11.50 \\
Meat \& Bone meal (M\&B) & $46.43 \pm 0.42$ & 14.55 \\
Mustard oil cake (MOC) & $48.91 \pm 0.07$ & 14.0 \\
Rice polishing (RP) & $30.32 \pm 0.28$ & 10.13 \\
& $10.50 \pm 0.1$ & 13.0 \\
\hline
\end{tabular}

Values are the mean \pm standard deviation; $N=3$

\subsection{Preparation of Enzyme Extract}

Live specimens of $C$. batrachus (average body weight $22 \mathrm{~g}$ ) were collected and reared on formulated fish feed (35\% protein) in the aquaria for three weeks until they were subjected for enzyme extraction. After rearing in the aquaria, the fishes were sacrificed by dissection to collect the guts. The guts of the species were pooled together, kept at chilled condition $\left(\leq 4^{\circ} \mathrm{C}\right)$ and weighted using electronic balance (Electric balance, model, D001, Japan) and homogenized in a Potter Thomas tissue grinder with a Teflon pestle at cool temperature $\left(\leq 4^{\circ} \mathrm{C}\right)$ by keeping the tissue grinder into ice and diluted with cool distilled water $\left(4^{\circ} \mathrm{C}\right)$ at a ratio of $1: 10\left({ }^{\mathrm{W}} / \mathrm{v}\right)$. The homogenate were poured into $1.5 \mathrm{ml}$ microfuge tubes (previously marked and kept into ice) and immediately centrifuge at 12000RPM for 15 minutes at $4{ }^{\circ} \mathrm{C}$ in a refrigerated centrifuge (Micro High Speed Centrifuge, VS-15000FN II). The upper lipid layer of the supernatant, after centrifuging, was discarded. The aqueous supernatant was collected in previously cooled glass bottle, frozen and stored at $-20^{\circ} \mathrm{C}$ until used. All the procedures was conducted at cool temperature $\left(\leq 4^{\circ} \mathrm{C}\right)[13]$.

\subsection{Determination of in Vitro Protein Digestibility using Fish Enzyme}

Between the two methods $\mathrm{pH}$ drop method using Lazo single enzyme assay and $\mathrm{pH}$ drop method using prawn's crude enzyme extract assay, here the first was done. At first the feed ingredients were finely ground for sample preparation. The ingredients were soaked with water for overnight at $4^{0} \mathrm{c}$. An equivalent amount of each ingredient that provided $240 \mathrm{mg}$ of crude protein, determined by the 
respective material's proximate analysis (Table1) was mixed with $30 \mathrm{ml}$ of distilled water and $3 \mathrm{ml}$ of gut enzyme to produce suspension of $8 \mathrm{mg}$ crude protein per milliliter. The mixture was kept at $\mathrm{pH} 8$ with the addition of dilute sodium hydroxide $(\mathrm{NaOH})$ or hydrochloric acid $(\mathrm{HCl})$. The $\mathrm{pH}$ was recorded at every minute interval for 10 minutes by $\mathrm{pH}$ meter ( $\mathrm{pH}$ meter, Sension3, HACH). Casein was chosen as the reference protein. The protein digestibility (PD) was calculated as the percentage of magnitude of $\mathrm{pH}$ drop $(-\Delta \mathrm{pH})$ of the ratio of ingredient and casein [9]. The RPD of different feed ingredients was calculated by the following equation-

$$
\operatorname{RPD}(\%)=\frac{-\Delta \mathrm{pH} \text { of ingredients }}{-\Delta \mathrm{pH} \text { of casein }} \times 100
$$

\subsection{Statistical Analyses}

Spread sheet analysis of data was done using Microsoft Excel. One way single factor analysis of variance (ANOVA) followed by Duncan's Multiple Range Test was done using SPSS 16.0 [14].

\section{RESULTS AND DISCUSSIONS}

The in vitro protein digestibility assays of different feed ingredients were conducted by using the $\mathrm{pH}$ drop method and the results were obtained by changing of $\mathrm{pH}$ of casein and feed ingredients.

\section{1.pH Change of Casein and Different Feed Ingredients}

The initial $\mathrm{pH}$ of casein or other different feed ingredients solutions were around 8.00. All the ingredients and casein solutions were hydrolyzed by the crude enzyme extract of $C$. batrachus for 10 minutes at room temperature. The final $\mathrm{pH}$ of casein solution after incubation was around 7.41 and the changes of $\mathrm{pH}$ of fish meal, soybean meal, meat and bone meal, mustard oil cake and rice polishing in C. batrachus were around 7.48, 7.61, 7.43, 7.59, and 7.79 respectively (Fig 1).

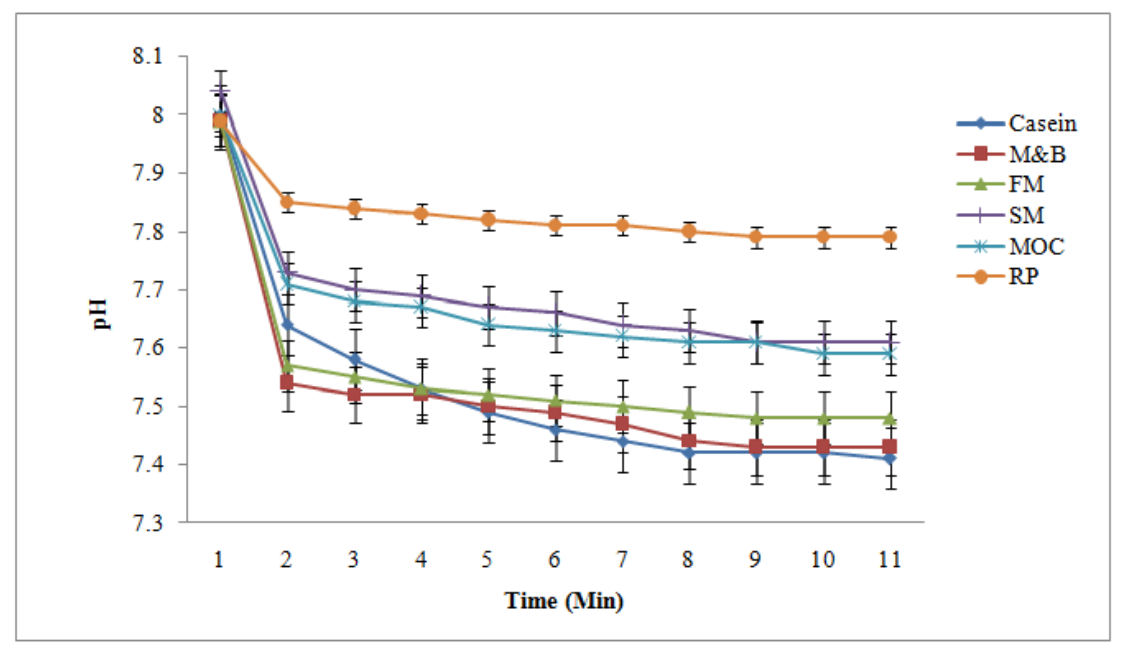

Fig1. $p H$ changes of casein and different feed ingredients

\subsection{Relative Protein Digestibility}

In this study the relative protein digestibility of meat and bone meal shows the highest rate as $94.92 \pm$ $0.00 \%$ (Fig. 2)and followed by fish meal $(86.44 \pm 1.69 \%)$ and then soybean meal $(74.01 \pm 2.59 \%)$, mustard oil cake $(69.49 \pm 0.00 \%)$ and rice polishing $(33.90 \pm 0.00 \%)$.

Though the protein digestibility of meat \& bone meal $(94.92 \pm 0.00 \%)$ is significantly higher $(P<0.05)$ than fish meal $(86.44 \pm 1.69 \%)$ but protein percentage is higher in fish meal $(53.35 \pm 0.29 \%)$ and followed by meat $\&$ bone meal $(48.91 \pm 0.07 \%)$ (Table1). The reason may be the enzymes of the fish body that take part in protein digestion. The digestibility of any protein depends on the ability of the fish to utilize ingested nutrients. For this, in spite of having highest protein percentage of fish meal, its digestibility is less than that of meat \& bone meal.

Again in vitro RPD of the meat and bone meal $(94.92 \pm 0.00 \%)$ is significantly $(P<0.05)$ higher than the other ingredients which is supported by the authors [15] as the relative protein digestibility of meat and bone meal for Nilotica (Oreochromis niloticus) is about $95.12 \pm 0.065 \%$. 
The higher RPD of fish meal and soybean meal using $C$. batrachus enzyme extract in this study is supported by the statement of the authors [16] who used Thai koi (Anabas testudineus) gut enzyme to determine the protein digestibility of different protein sources and reported the higher protein digestibility of fish meal $(78.08 \pm 0.36 \%)$ and soybean meal $(76.08 \pm 0.54 \%)$ by in vitro assay. It is also supported by the authors [15] who reported that the relative protein digestibility of fish meal and soybean meal for Nilotica (Oreochromis niloticus) are $86.02 \pm 0.054 \%$ and $78.27 \pm 0.093 \%$ respectively.

The lower RPD of rice polishing in C. batrachus is $33.90 \pm 0.00 \%$, which is justified by the statement of the authors[16] who conducted experiment on Thai koi (Anabas testudineus)gut enzyme to determine the protein digestibility of different protein sources and reported the protein digestibility of rice polishing is about $35.86 \pm 0.35 \%$.

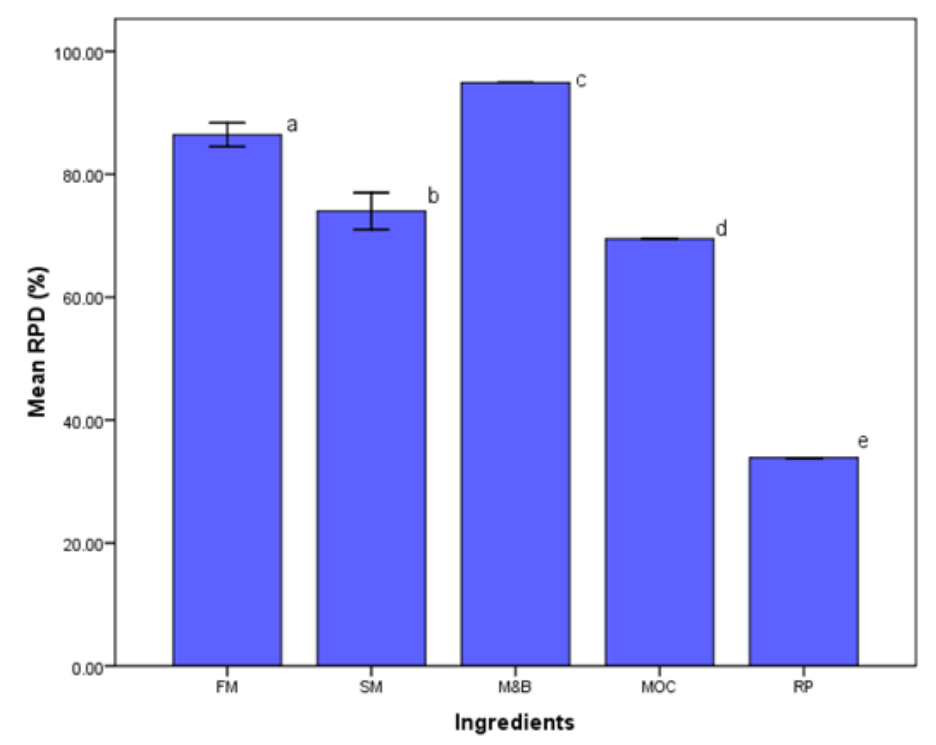

Fig2. Comparison of relative protein digestibility among different feed ingredients

Values are the mean \pm standard error; $N=3$; Different letter superscripts of the bars indicate the digestibility are significantly different $(P<0.05)$

Relative protein digestibility of mustard oil cake $(69.49 \pm 0.00 \%)$ is comparatively lower than meat \& bone meal, fish meal and soybean meal. It is supported by the researchers [15] who reported that the relative protein digestibility of mustard oil cake for Nilotica (Oreochromis niloticus) is about $67.95 \pm$ $0.105 \%$.The result can be justified with the statement of New (1987) who stated that dried mustard oil cake is often poorly produced and the protein may be damaged and the leucine or isoleucine ratio may be unbalanced which reduce the protein digestibility of mustard oil cake in C. batrachus.

From the findings of this study it was observed that the M\&B, FM and SM carried the higher digestibility and there is a significant difference among the digestibility of different feed ingredients.

\section{CONCLUSION}

Clarias batrachus was able to digest protein of the animal ingredients (meat \& bone meal, fish meal) more efficiently than plant ingredients (soybean meal, mustard oil cake \& rice police). The in vitro protein digestibility data would be useful in providing a suitable and reliable estimation of protein nutritional quality in different fish feed. The ingredient with high digestibility is more suited for feed formulation for the respective species. In this experiment the fish meal, meat \& bone meal and soybean meal were found better for feed formulation and could become together the alternative protein source for Clarias batrachus diet preparation.

\section{REFERENCES}

[1] Akiyama, D.M., Dominy, W.G. and Lawrence, A., 1992. Penaeid shrimp nutrition In: Marine Shrimp Culture: Principles and practices, Fast, A.W. and Lester, J. (ed.) Elsevier, Amsterdam, pp. 535-567.

[2] Fenerci, S. and Sener, E., 2005. In vivo and in vitro protein digestibility of Rainbow Trout (Onchorynchu s mykiss Walbaum, 1972) Fed steam pressured and extruded feeds. Turkish Journal of Fisheries and Aquatic Sciences, 5: 17-22. 
[3] Siddique, T. Q. and Khan, M. A., 2008. Effects of dietary protein levels on growth, feed utilization, protein retention efficiency and body composition of young Heteropneustes fossilis (Bloch). Fish Physiol Biochem, 35:479-488.

[4] Sklan, D., Prag, T. \&Lupatsch I., 2004. Apparent digestibility coefficients of feed ingredients and their prediction in diets for tilapia Oreochromis niloticus $\times$ Oreochromis aureus (Teleostei, Cichlidae). Aquaculture Research, 35: 358-364.

[5] Asad, F., Selim, M., Shahzad, K. \& Noreen, U., 2005. Estimation of Apparent Digestibility Coefficient of Guar, Canola and Meat Meal for Labeorohita. International Journal of Agriculture and Biology, 5: 816819.

[6] Lemos, D., 2006. Measuring protein quality in vitro using hepatopancreas extracts from shrimp. Aqua Feeds: Formulation \& Beyond, Vol. (3) 4.

[7] Dimes, L.E. and Haard, N.F., 1994. Estimation of protein digestibility-I. Development of an in vitro method for estimating protein digestibility in salmonids. Comp. Biochem. Physiol., 108 (A): 349-362.

[8] Lee, P.G. and Lawrence, A.L., 1997. Digestibility In: D’Abramo, L.R., Conkin, D.E., Akiyama, D.M. (Eds.), World Aquaculture Society, LA, Crustacean Nutrition, Advances in World Aquaculture, Vol. (6): 194-260.

[9] Lazo, J.P., 1994. Evaluation of several in vitro enzyme assays for estimating in vivo apparent protein digestibility by the Pacific white shrimp (Penaeus cannamel). Master of Science Thesis, Instituto Tecnologicoy de Estudios Superiores de Monterrey, Mexico, p.63.

[10] Wreed, J. H. V., 1995. Nutrition and growth in Clariasspecies - a review. Aquatic LivingResourceIFREMER-Gauthier-Villars, 8: 395-401.

[11] Hossain, Q., Hossain, M. A. \& Parween, S., 2006. Artificial breeding and nursery practice of Clariasbatrachus (Linnaeus, 1758). Scientific World, Vol. (4) 4.

[12] AOAC (Association of Official Analytical Chemists), 1980. Official methods of analysis Association of the Official Analytical Chemists, 13th ed. Arlington, VA.

[13] Chisty, A.H., 2005. Partial protease characterization, in vitro Protein digestibility and utilization of dietary soybean in Giant fresh water prawn, Macrobrachium rosenbergii (DeMan) (PhD thesis), University Sains, Malayasia, p.78.

[14] Steel, R.G.P. and Torrie, J.H., 1988. Bioestadystica, Principionsy procedimientos. Mc Graw-Hall, USA, p.622.

[15] Sultana, Z., Ahmed, M. S., Iqbal, M. S. \& Chisty, A. H., 2010. Determination of in vitro protein digestibility of different feed ingredients for Nilotica (Oreochromis niloticus). Bangladesh Research Publication Journal, 4(1): 87-94.

[16] Ali, H., Haque, M. M., Chowdhury, M. M. R. \& Shariful, M. I., 2009. In vitro protein digestibility of different feed ingredients in Thai koi (Anabas testudineus). Journal of Bangladesh Agriculture University, 7(1): 205-210.

Citation: S. Debnath, "Evaluation of in vitro Protein Digestibility of Different Feed Ingredients for Walking Catfish (Clarias batrachus Linnaeus, 1758)", International Journal of Research Studies in Biosciences (IJRSB), vol. 5, no. 9, pp. 59-63, 2017. http://dx.doi.org/10.20431/2349-0365.0509010

Copyright: (C) 2017 Authors. This is an open-access article distributed under the terms of the Creative Commons Attribution License, which permits unrestricted use, distribution, and reproduction in any medium, provided the original author and source are credited. 